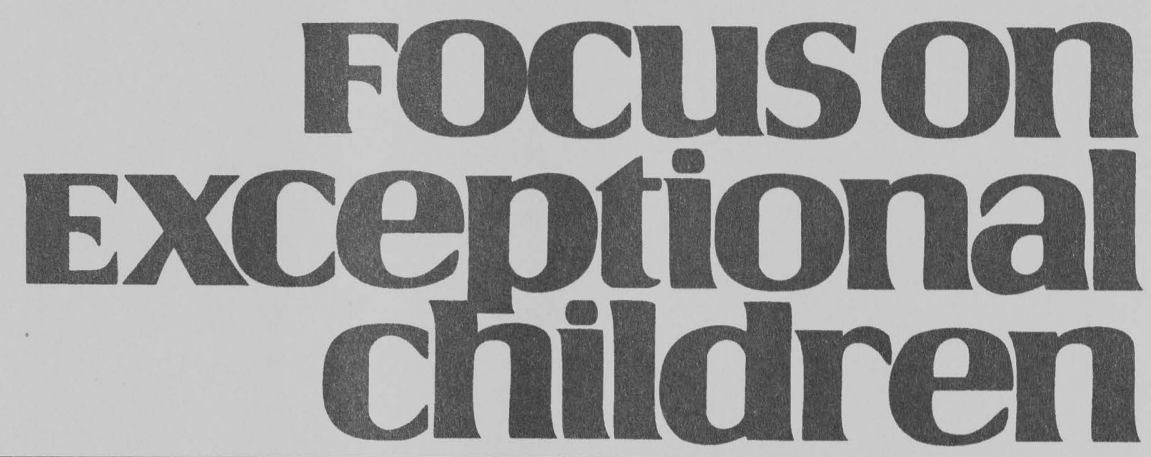

\title{
Selecting Instructional Strategies for Gifted Learners
}

\author{
Joyce VanTassel-Baska
}

Teachers employ certain techniques and delivery systems in the classroom to provide appropriate curricula to gifted learners. Most instructional strategies have some value in working with the gifted, but those strategies that allow for more open-ended, interactive, and generative learning behavior are probably most beneficial.

How do we know what strategies work? One way is to examine the strategies used in exemplary programs that reflect positive growth gains for gifted learners. Four programs that meet this criterion are the William and Mary language arts and science curriculum, Junior Great Books, Philosophy for Children, and Man: A Course of Study (MACOS). Students exposed to these programs have demonstrated growth gains in critical thinking and interpretation of written material (Lipman, 1988; Norris, 1985; Sternberg \& Bhana, 1986; VanTassel-Baska, Zuo, Avery, \& Little, 2002), and scientific research skills (VanTasselBaska, Bass, Ries, Poland, \& Avery, 1998). The common instructional strategy across these programs is inquiry, the use of questions to stimulate and expand thinking about what has been read, experienced, or seen. Thus, gifted educators typically promote inquiry and question asking as key elements in gifted programs.

Another way to ascertain effective strategies is to observe what exemplary teachers of the gifted do to facilitate growth in their students. Martinson (1974) developed an observational rating scale for recording the behaviors of gifted teachers. Subsequent adaptations to that scale have sought to extend our understanding of teacher behaviors based on general teacher education research as well as our understanding of what works with the gifted (VanTassel-Baska, 1995). The behaviors evaluated in teachers of the gifted in the Saturday and summer programs at the College of William and Mary consist of the following:

1. Plans curriculum experiences well.

2. Demonstrates understanding of the educational implications of giftedness.

3. Uses various teaching strategies effectively.

4. Selects questions that stimulate higher-level thinking.

5. Stimulates and models critical thinking skills in appropriate contexts.

6. Stimulates and models creative thinking techniques.

7. Stimulates and models problem-solving techniques.

8. Conducts group discussions well.

9. Encourages independent thinking and open inquiry.

10. Understands and encourages student ideas and student-directed work.

Dr. Joyce Van Tassel-Baska is Professor of Education and Executive Director of the Center for Gifted Education at The College of William \& Mary in Virginia. This article is adapted from Curriculum Planning \& Instructional Design for Gifted Learners by Joyce VanTassel-Baska, Love Publishing Company, 2003. 
11. Synthesizes student assessment data and curriculum content effectively.

12. Provides for student extension activities outside of class.

13. Promotes a healthy teaching-learning climate.

Source: Center for Gifted Education, College of William \& Mary, 1998.

Still another approach to examining effective strategies for the gifted is to focus on student outcomes and then identify the desired teacher behaviors that would facilitate those outcomes. Shulman (1987) cited the importance of linking teacher behaviors to student outcomes in his innovative assessment model. Table 1 demonstrates this process using common outcome statements from typical gifted programs.

\section{GUIDELINES FOR CHOOSING APPROPRIATE STRATEGIES}

Appropriate instructional strategies for gifted learners include all of the strategies deemed appropriate for other learners as well, and all teachers of the gifted should be

\section{FOcuson Exceptional children}

ISSN 0015-511X FOCUS ON EXCEPTIONAL CHILDREN (USPS 203-360) is published monthly except June, July, and August as a service to teachers, special educators, curriculum specialists, administrators, and those concerned with the special education of exceptional children. This publication is annotated and indexed by the ERIC Clearinghouse on Handicapped and Gifted children for publication in the monthly Current Index to Journals in Education (CIJE) and the quarterly index, Exceptional Children Education Resources (ECER). The full text of Focus on Exceptional Children is also available in the electronic versions of the Education Index. It is also available in microfilm from Xerox University Microfilms, Ann Arbor, MI. Subscription rates: Individual, \$36 per year; institutions, $\$ 48$ per year. Copyright (c) 2003, Love Publishing Company. All rights reserved. Reproduction in whole or part without written permission is prohibited. Printed in the United States of America. Periodical postage is paid at Denver, Colorado. POSTMASTER: Send address changes to:

$$
\begin{gathered}
\text { Love Publishing Company } \\
\text { Executive and Editorial Office } \\
\text { P.O. Box } 22353 \\
\text { Denver, Colorado } 80222 \\
\text { Telephone (303) } 221-7333
\end{gathered}
$$

Edwin Ellis University of Alabama
Tim Lewis University of Missouri

\footnotetext{
Chriss-Walther Thomas
} University of Kansas

Erica J. Lawrence Editor
Stanley F. Love Publisher comfortable using discussion, inquiry, small-group and individual consultation, and problem-solving approaches. But how does one choose the appropriate strategy in a given situation? Some principles to consider when planning instruction and choosing strategies for gifted learners are as follows:

1. Strategies should relate to instructional purposes, curriculum, and setting. The choice of a strategy depends, in part, on the purpose of a given lesson and the nature of the curriculum being taught. For example, inquiry teaching is appropriate in many situations, but if the instructional purpose is to provide an overview of key ideas on China in an hour, inquiry may not be the best choice. The interrelationship of strategy with purpose, content, and time frames must be carefully examined.

2. Strategies should be diverse. Research on instructional methods for the gifted currently points to the desirability of using a variety of techniques. Smallgroup cooperative learning strategies, independent learning models, and large-group instruction all have their place in the instructional pattern for the gifted. Striving for a good balance among these three instructional approaches may be optimal.

3. Strategies should include several that are generative in nature. Effective teachers of the gifted rely on strategies that involve the gifted as active learners who are capable of generating new ideas and products of various kinds. A few key strategies that all teachers of the gifted should have in their arsenal include inquiry, problem solving, and discussion via careful question-asking techniques. If these techniques are not applied in gifted programs, students are deprived of an important aspect of their learning.

4. Strategies should provide a balance among active and passive activities. Although having students work independently in the classroom has much value, it carries the potential problem of overloading students with passive types of activities in which they are merely receiving information by doing work in isolation. Many of the best insights gifted students have are gained from interacting with one another and articulating ideas verbally. Consequently, educators of the gifted need to consider a balance among active and passive activities.

5. Strategies should mesh with the cognitive style of both teacher and learners. The individual learning styles of the gifted require a teacher's sensitivity to students' cognitive styles. At the same time, teachers need to know their own cognitive strengths and the instructional approaches they do best and try to cap- 


\section{TABLE 1 \\ Expected Student Behaviors Correlated With Teacher Behaviors}

\section{Outcome Statements}

By the end of Grade 4, gifted students will demonstrate enhanced ability to think creatively as evidenced by appropriate pre-post measures.

By the end of Grade 6, gifted students will improve their problem-solving skills as evidenced by pre-post application of novel problem sets.

By the end of Grade 8, gifted students will increase critical thinking skills in the areas of analysis and interpretation, inductive and deductive reasoning, and evaluation.
Teacher Behaviors

1. Teacher employs brainstorming.

2. Teacher encourages flexible thinking.

3. Teacher asks students to elaborate ideas.

4. Teacher engages students in developing generative ideas and products.

1. Teacher employs creative problem-solving model.

2. Teacher uses problem-solving heuristics in presenting ideas.

3. Teacher asks students to define problems in a question form.

1. Teacher has students evaluate situations, problems, issuses.

2. Teacher has students ask analytic questions.

3. Teacher has students generalize from concrete to abstract at advanced levels.

4. Teacher has students support generalizations in written and oral discourse.

5. Teacher has students interpret selected passages. italize upon them in classroom interactions. Teachers' recognition of their own and their students' cognitive styles, and their attempts to respond to those styles, maximize the outcome of learning.

6. Strategies should be subordinate to educational purpose. Occasionally the strategy, instead of what is taught, becomes the purpose. For example, brainstorming may become more important than the ideas being considered. When this happens, we have lost sight of why the technique is important to employnamely as a way of exploring important ideas. Group process should not be an end in itself but, rather, must be tempered by relevant content for exploration.

\section{PROGRAM STRATEGIES}

Figure 1 identifies six strategies that promote openended, interactive, and generative learning in the gifted. These are described in the following sections.

\section{Pacing}

Activities must move at a rate that is comfortable for the gifted. I am often reminded of a student in my class many years ago. He was young for the seventh-grade class and had an annoying habit of going under his desk whenever the pace of instruction slowed to accommodate others. This went on for a few class sessions, with stern commentary

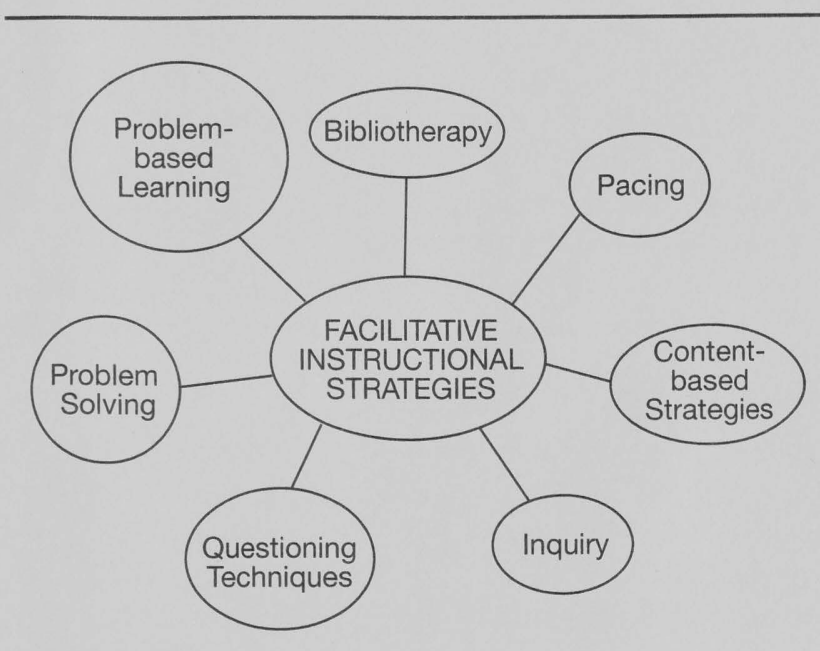

FIGURE 1

Key Strategies for Use With Gifted Learners 
from me regarding his appropriate physical placement in the classroom. Finally I made the connection between his behavior and the instructional pace. Once he was grouped with other learners also capable of moving more rapidly, he became a different learner before my eyes-rapt, interested in topics studied, and interactive with others.

Appropriate pacing also relates to limiting review of material already learned or providing only a quick summary of key points at the beginning of a new lesson. The gifted typically enjoy a rapid pace that matches their mental quickness.

Obviously, however, the pace should be deliberately slowed for some aspects of curriculum to allow more time for thinking about ideas and processing information. For some activities, such as writing, teachers must be sensitive to gifted students' individual capacities and allocate longer work periods as needed.

\section{Inquiry}

At the most expansive level, inquiry means creating a climate of mutual investigation into a problem, issue, or idea worthy of attention. Inquiry requires structuring a situation or activity in a way that elicits high-level thinking from learners. It involves asking open-ended and suggestive questions that lead the learner to think through a problem, issue, or idea in a deliberate way.

The use of inquiry techniques in gifted programs has long been supported in the literature as well as by enthusiastic teachers of the gifted who see its positive effects. Inquiry approaches work well with the gifted for several reasons. First, gifted learners usually can handle formal operational thought more readily than can other learners and thus grasp the discovery approach to learning more easily and quickly. The gifted have the insight to understand discrepant events in science, for example, within a class period, rendering this instructional approach extremely doable in most learning contexts.

Second, gifted learners generally have idiosyncratic knowledge of self. Because inquiry can honor many different ways of approaching and carrying out the learning task, it can be used to accommodate to the varying cognitive styles of the gifted.

Third, inquiry approaches work with this population because they are basically problem-centered. The gifted enjoy a good mystery, a puzzle, ambiguity, and paradox. Inquiry provides a learning context in which the gifted learner's curiosity can roam unchecked, and it sets the stage for these learners to choose their own problems to be solved in future independent investigations.

A clarifying example may lead to a better understanding of the inquiry process.
A. Stimulus Problem. Each student is given a Japanese print that depicts a scene in nature. Some of the prints have human figures; some do not. The inquiry task is to study the picture and provide written commentary for each of the following questions:

1. What objects do you see in your picture?

2. What ideas does your picture convey?

3. What feelings does your picture evoke?

4. If you were to identify with an object in your picture, what would it be, and why?

5. Based on your impressions, thoughts, and feelings about your picture, can you synthesize your reactions to the picture graphically or in written form?

B. Each student shares the picture he or she viewed with two or three other students and discusses individual reactions. Each group then responds to the following questions in a discussion context:

1. What similarities and differences exist among your pictures?

2. Compare and contrast your individual reactions to each picture. What did you discover?

3. Based on your experience, what generalizations might you make about the pictures?

4. Based on your experience, what generalizations might you make about one another?

C. In the framework of group sharing, the total class engages in a debriefing of each group's perceptions. Pictures and ideas are shared across the five to six groups in the room. The total group then responds to the following questions:

1. Based on your experiences with these prints, what do you know about the Japanese culture (its philosophy, art, geography, religion, etc.)?

2. What did you learn about one another from this experience?

3. What important generalizations might you make about cultural understanding from this experience?

D. Key generalizations that might be derived from this inquiry lesson include the following:

1. A culture is represented in its art at a symbolic level.

2. Studying artifacts (e.g., Japanese prints) helps us understand ourselves as well as others.

3. Cultural understanding is dependent on understanding multiple perspectives.

4. Knowing other people's perceptions about a given situation or problem helps us appreciate rather than denigrate individual differences. 
The inquiry lesson just described incorporates the nature of the activity, key questions, grouping arrangements, and anticipated outcomes of the lesson. The richness of the discovery, however, is left to individual gifted learners.

\section{Questioning Techniques}

Many educators of the gifted view effective questioning as employing a large number of higher-level questions. Other educators have successfully used techniques related to Socratic questioning, which force the student to think more deeply about the heart of an issue and explore it from many sides. From the teacher's standpoint, techniques related to Socratic questioning call for asking probing questions directed to central points.

The Junior Great Books Foundation, long a purveyor of key literature materials used in gifted programs, discourages teachers from asking either factual or evaluative questions. Rather, Junior Great Books recommends a focus on interpretive questions. It encourages the use of question clusters that direct the discussion along predetermined lines. Teachers are asked to read a story carefully and then single out the major aspect of interpretation, that area of the story that is intriguing to a reader because it has not been thoroughly explicated. The teachers then ask questions to help students explore this area. The following example helps to clarify the use of this technique.

In Shirley Jackson's classic short story, "The Lottery," the plot culminates in the stoning by her neighbors of one Mrs. Henderson, who drew the black spot on her paper in the lottery process. The story is intriguing because (a) there is no real reason the lottery is being held; only tradition and rituals keep it going; (b) the townspeople have no reason to punish one of their own, for no crime has been committed against their society; thus (c) the sheer horror of the act is overwhelming to the reader. What is horribly open to interpretation in this story is why the townspeople stoned an innocent woman and why this lottery ritual has been allowed to continue in the village. Thus, a question cluster for a 45-minute discussion with sixth-grade gifted student might be:

1. From the story, what do we know about Mrs. Henderson? About her husband? About others in her family?

2. Why, according to the author, does the town carry out a lottery?

3. What signs of foreboding are there in the story before the final act occurs?

4. What clues does the author provide that the ending of the story will be tragic?
5. Why do the townspeople carry out the stoning? What does this act reveal about their character?

6. A lottery usually represents "equality of opportunity"; in state lotteries, for example, people have equal opportunity to win prizes. How does Jackson treat this idea of "equality of opportunity" in the story?

In addition, many inquiry-based question paradigms have been developed. Sanders (1966) introduced several, and others including Barth and Shermis (1981) modified them for "goodness of fit" with a specific content domain. The Barth approach, as shown in the following chart, utilizes parts of the Guilford's structure of intellect model as the underlying organizer for developing a question set in social studies:

\section{Question Type}

Memory/cognition

Convergent

Divergent

Evaluative

\section{Key Question}

Who started the Civil War? Why was the conflict begun? What if the South had won the war? What might have occurred differently in the United States from 1865 to 1900 in this country? In your opinion, who was the most impressive Civil War general? Why?
The Barth model also can be applied easily to language arts and literature, as can be seen in the following question set for the charming African folktale Bringing the Rain to Kapiti Plain by Verna Aardema.

\section{Memory/Cognition}

1. What caused the grass to turn brown?

2. What other things happened as a result of no rain?

3. What did Kipat do to solve the problem of no rain?

\section{Convergent}

1. What important qualities did Kipat have?

2. Why did Kipat think of using a feather?

3. How does this story show the relationship of cause and effect in nature?

4. Why did the author end the story with Kipat's son tending the herds?

\section{Divergent}

1. Pretend you were a herdsman in Africa at the time of the story. What obstacles would you face in carrying out your job?

2. What if the cows had died? How might the story have been different? 


\section{Evaluative}

1. Why do you think Kipat waited as long as he did to get married?

2. What did you think of the way the author used rhyme to tell the story?

3. In your opinion, what is the best part of the story? Why?

Another effective questioning strategy has been used in the Great Books study program. This model is particularly effective with secondary-level gifted students. Students begin by reading a passage and responding to hypothetical situations. Next, they discuss the meaning of the passage, and they link ideas in that work to the real world of applications. The technique is shown in the following example.

\section{Sample Reading Passage*}

Can poverty in the United States be abolished within the limits of the welfare state?

The answer is clear enough. The government's own figures demonstrate that the current antipoverty programs are basically inadequate. I do not, however, want to dismiss completely the government's antipoverty programs. Current serious discussion of poverty in this country is a gain which one owes in part to that program. But there is no point in pretending that a little more welfarism will do away with a national shame.

Today's poor are different from the pre-Second World War poor. The "old" poor lived at a time when economic opportunity was the national trend, when the net income from the growth of American manufacturing increased by 4,500 percent. It was the "old" poor, mostly Eastern European immigrants unified by language and culture, who created the big-city political machines and participated in the organization of unions and the political struggle for the New Deal. They had objective, realistic reason for hope.

An analysis of the first phase and second phase of the New Deal of the Roosevelt administration is quite relevant at this point. The first phase of the New Deal, supported by American business and dominated by the National Recovery Act, gave recognition to an old corporate dream-economy planned by business. The second phase of the New Deal (the source of today's welfare theory and antipoverty wisdom) moved away from the concept of planning and toward a "free

* Passage reprinted from College Entrance Examination Board (1983). 10 SATs. New York: Author. market." The assumption was that in its intervention the government should not plan but should stimulate the economy and that the private sector and initiative would continue to be the mainspring of progress.

After the Second World War, the government started emphasizing training programs because some workers were not participating in the general economic advance. However, these training programs have missed the fundamental problem. The novelty of impoverishment today is that it takes place in a time of automation. The government offers education and training and at the same time admits that the jobs for its graduates are obsolete. Such hypocrisy reinforces the cynicism and resistance to organization which characterize poor communities.

It is therefore crucial that the federal government generate jobs and create an environment of economic hope. The essence of the "third phase" of the New Deal would be social investment, a conscious and political allocation of resources to meet public needs. This New Deal would be dependent upon a coalition, which would include but not be confined to, the poor, that would see to it that planning and social investment were extended in a democratic way.

\section{Opening Questions}

1. Propose a title for the passage. What is your title?

2. What audience would be interested in reading the passage? Why do you think so?

3. How would the President of the United States react to this passage? Why?

4. What public figures would agree with the perspective in the passage? Would any of our American presidents?

\section{Core: Examining Central Points}

1. According to the passage, is it possible for: Yes No

_ a. poverty to be abolished?

II levels of economic opportunity?

c. poverty to be reduced in the current free market atmosphere?

d. job training programs to solve the problem of poverty? nomic hope?

e. America's poor today to have eco-

2. How would you rank order the following ideas for dealing with poverty in America, based on the perspective of the author of this passage?

world marketplace.
$\mathrm{Be}$ more competitive in the 
Stimulate the economy.

Create coalitions of support for social investment.

Return to earlier phases of the New Deal.

Let business plan the economy.

Reduce hopelessness among the poor.

Which did you rank first? Why?

Which did you rank last? Why?

\section{Closing: Relating to the World}

1. If fighting poverty requires "social investment," how might that approach be undertaken?

2. At what levels can this concept of "social investment" be employed? (neighborhoods, social community, states, at a global level)

3. How "marketable" is this idea in today's world?

These examples of questioning techniques represent some of the many approaches that are effective with gifted learners. Whatever technique is used, practitioners should consider the following when making decisions about questions to be asked:

1. What is the purpose of each question and of the string or cluster of questions? Do they individually and collectively contribute to greater student understanding of the work under study?

2. Are the questions interesting to you? Would you like to discuss them?

3. Do the questions encourage students to think more deeply about a story or event?

4. Do the questions encourage discussion and dialogue?

5. Do the questions raise issues, themes, and problems central to the story or event?

6. Will the questions carry a discussion for $\mathbf{4 5}$ minutes, without the need for teacher intervention?

All of the approaches cited here have to be preceded by students' careful reading of the assigned text material, for the questioning techniques are predicated on students' having sufficient knowledge and comprehension of the reading material to be able to discuss ideas intelligently. Questioning strategies can be effective only if students are prepared to engage in the inquiry process.

\section{Problem Solving}

Various forms of problem solving have been promoted for use with the gifted. One of the most frequently used has been the model of creative problem solving popularized by
Parnes (1975) and Feldhusen and Treffinger (1979) and later refined by Treffinger, Isaksen, and Dorval (1994). This model places equal emphasis on the processes of problem finding and problem solving and allows students to develop a self-generated plan of action. Because the model is highly structured and moves from divergent to convergent inquiry with some regularity, it provides an excellent context in which to teach the importance of both types of inquiry for generating a worthwhile "product." The model is delineated as follows (Parnes, 1975):

\section{Creative Problem Solving}

1. Fact finding: gathering data in preparation for defining the problem

$\checkmark$ Identify the problem by asking questions: Who? What? Where? When? Why?

2. Problem finding: analyzing problematic areas in order to pick out and point up the problem to be attacked

$\checkmark$ Question: "In what ways might I . . ?"

$\checkmark$ Gather data

3. Idea finding: idea production-thinking up, processing, and developing numerous possible leads to solutions

$\checkmark$ Put to other uses

$\checkmark$ Modify

$\checkmark$ Magnify

$\checkmark$ Rearrange

$\checkmark$ Combine

$\checkmark$ Adapt

$\checkmark$ Minimize

$\checkmark$ Substitute

$\checkmark$ Reverse

4. Solution finding: evaluating potential solutions against defined criteria

$\checkmark$ Establish criteria

$\checkmark$ Evaluate

$\checkmark$ Verify

$\checkmark$ Test

5. Acceptance finding: adoption-developing a plan of action and implementing the chosen solution

$\checkmark$ Implement

$\checkmark$ Prepare for acceptance

An activity using the creative problem-solving model for gifted students in a secondary English classroom might include the following guided inquiry:

\section{Problem Generation}

A. What are all the problems faced by characters in important American novels we have read? (brainstorm problems) 
B. What are the most critical and general problems? (pick three, then one)

\section{Problem Clarification}
A . Where are illustrations of the prob- lem?
B. What are things that cause the problem?
C. What are further problems caused by the problem?

\section{Problem Identification}

B. State the problem as a "how" question.

\section{Idea Finding}
A. What could the character do?
B. Brainstorm solutions.

\section{Synthesizing a Solution}
A. Select the best elements from Stage IV.
B. Develop a comprehensive solution.
C. Does it fit the problem statement?

\section{Implementation}
A. Who?
B. How?
C. What order of events?
D. State precautions, obstacles.
E. State how to overcome obstacles.

\section{Problem-Based Learning}

In problem-based learning, teams of four to five students work together to seek a solution to an ill-structured realworld problem that is relevant to a key area of school learning. The teacher facilitates their learning about the problem through providing heuristic tools, such as the three-part "need-to-know board" (used to ask: What do I know, what do I need to know, and how can I find out?), and posing probing questions about their understanding as it emerges. The teacher's instructional approach shifts throughout the problem episode depending on the support students need for various aspects of their work on the problem. Results from the use of this strategy with both elementary and secondary gifted students appear promising (Boyce, VanTassel-Baska, Burruss, Sher, \& Johnson, 1997; Stepian \& Gallagher, 1993).

Table 2 compares features of problem-based learning to those of creative problem solving (Parnes, 1975; Treffinger et al., 1994) and a more generic inquiry-based learning model (Joyce \& Weil, 1996). All three models begin with a problem that is in some stage of disarray. In creative problem solving, the problem emerges from a discussion in which students identify that a problem exists, clarify the problem by providing illustrations and examples, and ultimately pose the problem as a question to be answered by further study. In general inquiry, students are presented with a puzzling situation and asked to derive meaning from it (Suchman, 1964). The problem may be real world or not and broad or narrow in its orientation. For example, students may be asked what a poem or a specific war in history means, or they may be asked what happened in a specific scientific demonstration. In problem-based learning, students are confronted with an ill-structured, real-world problem for which there may not be a clear-cut solution. Thus, the learner is drawn into a complex reality.

The role of the teacher varies in the three models. In creative problem solving, the teacher is clearly a facilitator of group process, for part of the learning to be achieved is related to the students' internalization of the heuristic steps in a collaborative group context. Newer versions of the creative problem-solving model stress the naturalistic processes employed by problem solvers in the real world and, thus, encourage a more flexible use of the specific steps of the strategy (Treffinger, 1995). In general-inquiry models, the teacher focuses on developing and posing open-ended, suggestive questions that encourage thought about the problem. The teacher typically arranges the questions in a careful hierarchy that assists students in exploring the subject at increasingly complex levels of thought. In problem-based learning, the role of the teacher is more complex. The model requires an ongoing, dynamic interaction between the teacher and individual learners and small groups of learners to assess their level of mastery related to both content and process considerations. Teaching interventions include but are not limited to questioning, developing group activities, initiating student self-study, and recommending a visit to a key resource person. Because of the broad purposes of this methodology, the instructional component tends to be diverse.

The role of the learner in all three models is to develop meaning. However, the means of constructing meaning and the nature and extent of the meaning derived differ among the models. In creative problem solving, meaning emerges from the manipulation of a prespecified and evolving process. In the more traditional inquiry models, meaning is derived from the careful examination of several perspectives sifted through a set of analytical and interpretive questions. In problem-based learning, the need-to-know board functions as the basic inquiry device. Students use it recursively to ask: What do I know, what do I need to know, and how do I find out? Meaning is derived through in-depth reiteration of the need-to-know heuristic as the inquiry process proceeds; thus, the approach represents a holistic and integrated method of self-learning that encourages depth and complexity of understanding. 


\section{TABLE 2}

\section{Comparison of Creative Problem Solving, Inquiry, and Problem-Based Learning}

\begin{tabular}{llll} 
Dimension & $\begin{array}{l}\text { Creative } \\
\text { Problem Solving }\end{array}$ & Inquiry & $\begin{array}{l}\text { Problem-based } \\
\text { Learning }\end{array}$ \\
\hline $\begin{array}{l}\text { Nature of the } \\
\text { problem }\end{array}$ & $\begin{array}{l}\text { Starts with a } \\
\text { discussion in which } \\
\text { learners seek to } \\
\text { understand the } \\
\text { problem }\end{array}$ & $\begin{array}{l}\text { Starts with the } \\
\text { presentation of a } \\
\text { puzzling situation }\end{array}$ & $\begin{array}{l}\text { Starts with the } \\
\text { presentation of an } \\
\text { ill-structured, } \\
\text { real-world problem }\end{array}$ \\
Role of the teacher & $\begin{array}{l}\text { Facilitator of } \\
\text { group process }\end{array}$ & Question poser & Metacognitive coach \\
Role of learners & $\begin{array}{l}\text { Construct meaning } \\
\text { through generating } \\
\text { ideas }\end{array}$ & $\begin{array}{l}\text { Construct meaning } \\
\text { through questions, } \\
\text { data collection, } \\
\text { and analysis }\end{array}$ & $\begin{array}{l}\text { Construct meaning } \\
\text { through metacognitive } \\
\text { and scientific heuristics }\end{array}$ \\
$\begin{array}{l}\text { Application or } \\
\text { transfer of learning }\end{array}$ & $\begin{array}{l}\text { Application of plan } \\
\text { to action }\end{array}$ & $\begin{array}{l}\text { Application to } \\
\text { conceptual }\end{array}$ & $\begin{array}{l}\text { Application to } \\
\text { real world }\end{array}$ \\
\hline
\end{tabular}

A final point of comparison relates to the application or transfer of learning. In creative problem solving, the transfer of learning is to a plan of action that is worked out in detail to the level of citing potential barriers to implementing the plan and ways to overcome those barriers. In the generalinquiry framework, the application of learning is to conceptual understanding of a set of ideas or principles that influence an event or an artistic product. In problem-based learning, the application of learning is intended to extend beyond process and conceptual understanding to real-world utilization. Asking students, for example, to develop policy positions for real-world problems and then to articulate them to relevant adult audiences elevates the level of learning. Students have to consider the complexity inherent in real-world problem resolutions, not solutions, and the inherent conflicts of various stakeholders. Thus, the learning transfers directly to life.

The intent of this comparison is to convey the sense of sophistication of using problem-based learning as an overarching approach that can include creative problem solving and general-inquiry models. Because its perspective is broad and focused on developing self-directedness in the learner, problem-based learning can serve as an umbrella for other inquiry-based perspectives. For a relevance-based curriculum, problem-based learning is a highly valuable tool, for it competently engages the learner in constantly asking, "What makes this (learning) important to me and my life?"
In the William and Mary science units, problem-based learning provides an important catalyst for student learning in three major areas. Conceptual learning about systems was addressed by infusing the problem that was posed with opportunities for students to understand interrelated social, political, economic, and scientific systems in the real world. The scientific research process was learned through an emphasis on using experimental design techniques to tackle the scientific aspects of the problem. Science-content learning accrued through access to science resources that focused on specific, targeted learning. Thus, problem-based learning wrapped around a set of challenging outcomes. Preliminary studies of student learning resulting from employing the William and Mary units for at least 25 hours of instruction showed significant growth gains in the outcomes associated with integrated science process and demonstrated enhanced student and teacher motivation in science learning (VanTassel-Baska, Bass, Ries, Poland, \& Avery, 1998).

When teachers were asked about unanticipated effects of using the units, they often reported increases in their own learning, especially of science content. One teacher remarked that she discovered that reading about archaeology was fun. Another said that she studied more than usual in order to effectively teach the units but that she liked learning new information. Equally important, teachers reported a new understanding of gifted learners. They commented on a greater appreciation of the problem-solving 
abilities of gifted learners and the need for a differentiated curriculum. The dynamic nature of problem-based learning resulted in true inquiry, with teachers learning alongside the students.

\section{Bibliotherapy}

The approaches discussed thus far relate to cognitive learning. Key instructional approaches also are valuable for working with the gifted in the psychosocial domain. These approaches can be used by both teachers and parents, who many times are in an excellent position to provide guidance to students in several areas of psychosocial development. The techniques often are integral to other teaching and learning activities that take place in the classroom. One of these approaches is bibliotherapy, the use of books to help learners reach important understandings about themselves and others. Deliberately choosing books that have a gifted child as a protagonist is an excellent way to help gifted students identify some of their own problems in others. Through discussion, these students can come to new awareness about how to cope with their problems. An example follows:

Problem identified: Understanding differences Book: Lord of the Flies

Key questions (to be answered individually in writing and then discussed as a group)

\section{$\checkmark$ Why did the group ostracize Piggy?}

$\checkmark$ What might Piggy have done to prevent such treatment?

$\checkmark$ According to the author, what happens to people who feel rejected?

$\checkmark$ Can you think of a time when you have felt rejected? How did you respond or react?

How might you have changed your behavior to obtain more favorable results?

An excellent teacher reference for this type of activity is a book entitled Some of My Best Friends Are Books (Halsted, 2002).

A second area of psychosocial development that a teacher can help the gifted explore is their tendency toward perfectionism. By focusing on open-ended activities and leading students to engage in "safe" risk-taking behaviors, teachers can set a climate in which students are encouraged to accept that most situations in life do not have one right answer-rendering unimportant the standard the gifted often set to rate themselves and others on the way to "perfection." An example of an open-ended activity that promotes "safe" risk taking follows:
Pass out pictures (a different picture for each group of three students) that are linked to key pieces of literature by theme and impressionistic in style, and ask students to respond individually to these vital stimuli according to the following paradigm:

1. What did you observe in the picture? (Make a list of what you see.)

2. What ideas does your picture convey?

3. What feelings does your picture evoke?

4. If you were to identify with an object in your picture, what would you identify with, and why?

5. Now spend a few minutes synthesizing your observations, ideas, feelings, and reactions to your picture in whatever form you wish. You may choose, for example, to write a poem, draw a picture, or create a descriptive story.

After each student has responded to these questions and activities, have the members of each group discuss one another's perceptions of the group's picture. Then, if you wish, ask individual students to share their pictures and their reactions to them. Follow-up may include whole-group discussion of similarities and differences in the pictures and literature from which each was taken. This activity can also introduce a unit of study on cultural or individual differences.

A third area of psychosocial exploration with the gifted centers on the area of forming meaningful relationships and developing friendships. Books such as The Bunny Who Wanted a Friend, by Joan Berg, can be used as a key tool with primary-age students. The following example shows questions a teacher can ask to help elicit understanding of the strategies by which we gain friends.

1. What are all the reasons the bunny did not have a friend?

2. What was wrong with his method of making friends?

3. What was his "secret" to finally finding a friend?

4. What if you were the bunny? How would you have tried to make a friend?

5. Why were the bunny and the bird friends at the end of the story? List the reasons.

Both of these bibliotherapy strategies are viable for use with the gifted in both home and school settings. 


\section{Content-Based Strategies}

The six instructional strategies that have been discussed have salience in many subject areas, but they clearly will not work well in all areas. For that reason, teachers of the gifted must also develop content-based strategies for each of the major disciplines emphasizing higher-level thinking, the use of technology, constructivist activities, and interdisciplinary learning approaches. Although these themes cut across the subject areas, each discipline also retains its own unique set of strategies pedagogically linked to the content area under study. Educators of the gifted need to develop a strong understanding of these strategies and implement them effectively within content-based programs.

\section{MEDIATING LEARNING THROUGH INSTRUCTION}

Instructional processes mediate both the objective of any lesson and the receptivity level of students to that objective. Thus, the function of instruction, though not paramount, is critical to the enterprise of teaching and learning. It might be argued that the mode of instruction for gifted learners is less critical than for other learners, given the ability of the gifted to connect with content and their tendency to master it quickly and well. Yet, even the gifted need high-quality instruction to maximize their knowledge acquisition and minimize the time and energy taken up by lower-level work. If a teacher cannot mediate the knowledge acquisition process effectively for individual learners, the best curriculum plan and set of activities will go awry (Lebow, 1994).

How does one go about such mediation? Developing skills in areas such as discovery learning, inquiry, asking the right level questions, and using specific teaching paradigms is helpful, but merely manipulating process is insufficient for mediating curricula for the gifted. Gifted educators also must attend to manipulation of content in fundamental ways.

By way of example, consider the following activity set:

Discuss plot, setting, and characters in the short story "A Rose for Emily."

Compare and contrast the plot, setting, character motivation, and theme of "A Rose for Emily" and "The Bear."

The activity on the right, which is more appropriate for gifted students, engages learners in critical analysis as the foundational element of their manipulation of knowledge. Moreover, it seeks to have them use two stimuli to do so. Further, in addition to the basic elements of plot, character, and setting, it involves the more complex and abstract task of manipulating theme and character motivation.
If we agree that the activity on the right is more appropriate for gifted learners, what instructional mediation would enhance its use? A teacher of the gifted could:

$\checkmark$ hold a discussion in which students demonstrate their capacity to complete the activity in oral form.

$\checkmark$ have students develop an expository essay in class, and meet with students individually or in small groups to discuss their analysis.

$\checkmark$ lecture on key elements of short stories, and use the activity as a seatwork application of information for quizzing students on their understanding.

$\checkmark$ develop panel discussion groups that allow students to discuss and present as a group their critical analysis of the two stories.

$\checkmark$ engage students in creating a representational visual product, such as a videotape, mobile, slides, or collage, that conveys their analysis of the stories.

$\checkmark$ assign the activity as homework-a direct follow-up to a class lecture and discussion on short story elements.

Selecting the instructional process to use for this activity would depend on several factors:

1. Instructional time. Decisions about instructional process cannot be based solely on the relative importance of a given activity. They also must take time constraints into account. Some options are more time-consuming than others. If time is limited, a strategy that will work in the allotted time is most prudent.

2. Mixing of instructional processes. Choice of a process to accompany any activity is somewhat dependent on what processes preceded and will follow the activity. A variety of approaches works well with gifted learners.

3. Student need for a particular approach. The needs of gifted learners sometimes affect choice of instructional process. Perhaps students need more cooperative learning at a given point, or need to enhance expository writing skills, or need practice in orally articulating a perspective. Such needs then may become a criterion for choosing an instructional approach.

4. Effectiveness of a given approach with gifted learners. A meta-analysis of research on gifted learners demonstrated a high effect size for increased homework, a moderate effect size for active questioning and discussion, and a moderate effect size for inquiry-discovery teaching (Walberg, 1991). To make intelligent choices of strategies, we have to examine what we know about what works. For the three strategies cited, recognizing the role that each 


\section{FOCUSO Exceptional children}

could play in delivering curriculum would be an important perspective to have.

5. The nature of the activity itself. The choice of activity may make the choice of instructional process easier, for many activities call for the use of particular strategies. For example, the critical analysis activity described earlier may be thought of as basically a reflective activity, one in which gifted learners need considerable time to think about the two stories in depth. Therefore, an instructional process that honors thinking time may be a better choice than one that emphasizes quick response or group interaction skills.

Instructional choice, then, can best be made after all factors have been considered. As in other aspects of this curriculum design model, the emphasis is on careful thinking and planning of what to do.

\section{SUMMARY}

Instructional strategies are crucial in delivering curricula for the gifted learner. No curriculum is likely to be judged effective with gifted learners without careful choices regarding strategies. Alternative strategies include small groups, individual consultation, inquiry, questioning techniques, pacing, and problem solving. Many educators cite the importance of linking teacher behaviors to student outcomes. Exemplary teachers plan curricula well, use various teaching strategies, select questions that stimulate higherlevel thinking, foster critical thinking, creative thinking, and problem solving, encourage independent thinking and open inquiry, conduct group discussions well, promote studentdirected work, and provide a healthy learning environment, among other behaviors.

Problem-based learning is a promising umbrella approach to employ with gifted learners in that it heightens both the complexity of the tasks and the motivation of the learners. Use of research-based, content-based learning strategies also enhances the teaching-learning process for these students.

Bibliotherapy - the use of books to further learning - is another strategy that is particularly effective with the gifted. Through books, gifted students can gain insight by identifying their problems in others, exploring their tendency for perfectionism, and learning how to develop friendships.

In selecting which instructional strategies to use, the teacher has to consider the amount of time required, a mix of processes, individual need and effectiveness of a given approach with that learner, and the nature of the activity itself.

\section{REFERENCES}

Aardema, V. (1997). Bringing the rain to Kapiti Plain. Boston: Houghton Mifflin.

Barth, J. L., \& Shermis, S. S. (1981). Teaching social studies to the gifted and talented. Indianapolis: Indiana State Department of Public Instruction, Div. of Curriculum; Lafayette: Purdue University. (ED 212118).

Boyce, L. N., VanTassel-Baska, J., Burruss, J., Sher, B. T., \& Johnson, D. T. (1997). A problem-based curriculum: Parallel learning opportunities for students and teachers. Journal for the Education of the Gifted, 20 , 363-379.

Center for Gifted Education. (1998). A checklist of teacher behaviors in classrooms for the gifted. Williamsburg, VA: Author.

College Entrance Examination Board. (1983). 10 SATs. New York: Author.

Feldhusen, J., \& Treffinger, D. (1979). Creative thinking and problem-solving. Dubuque, IA: Kendall-Hunt.

Halsted, J. (2002). Some of my best friends are books. Scottsdale, AZ: Great Potential Press.

Joyce, B., \& Weil, M. (1996). Models of teaching (5th ed.). Boston: Allyn \& Bacon.

Lebow, D. (1994). Constructivist values for instructional systems design: Five principles toward a new mindset. Educational Technology Research and Development, 41, 4-16.

Lipman, M. (1988). Critical thinking-What can it be? Educational Leadership, 46(1), 38-43.

Martinson, R. (1974). Martinson-Weiner rating scale of behaviors in teachers of the gifted. In A guide toward better teaching for the gifted. Ventura, CA: Office of the Ventura County Superintendent of Schools.

Norris, S. P. (1985). Synthesis of research on critical thinking. Educational Leadership, 42(8), 40-45.

Oakes, J. (1985). Keeping track: How schools structure inequality. New Haven, CT: Yale University Press.

Parnes, S. (1975). Aha! Insights into creative behavior. Buffalo, NY: DOK.

Sanders, N. M. (1966). Classroom questions: What kinds? New York: Harper \& Row.

Shulman, L. S. (1987). Assessment for teaching: An initiative for the profession. Phi Delta Kappan, 69, 38-44.

Stepien, W., \& Gallagher, S. (1993). Problem-based learning: As authentic as it gets. Educational Leadership, 50(7), 25-28.

Sternberg, R. J., \& Bhana, K. (1986). Synthesis of research on the effectiveness of intellectual skills programs: Snake-oil remedies or miracle cures? Educational Leadership, 44(2), 60-67.

Suchman, J. R. (1964). Illinois studies in inquiry training. In R. E. Ripple \& V. N. Rockcastle (Eds.), Piaget rediscovered: Report of the Conference on Cognitive Studies and Curriculum Development (pp. 105-108). Ithaca, NY: Cornell University Press.

Treffinger, D. J. (1995). Creative problem solving: Overview and educational implications. Educational Psychology Review, 7, 301-312.

Treffinger, D. J., Isaksen, S. G., \& Dorval, K. B. (1994). Creative problem solving: An overview. In M. A. Runco (Ed.), Problem finding, problem solving, and creativity (pp. 223-236). Norwood, NJ: Ablex.

VanTassel-Baska, J. (1995). Comprehensive curriculum for gifted learners. Boston: Allyn \& Bacon.

VanTassel-Baska, J. (1998). Planning science programs for high-ability learners. (ERIC briefs). Reston, VA: Council for Exceptional Children.

VanTassel-Baska, J., Bass, G. M., Ries, R. R., Poland, D., \& Avery, L. (1998). A national pilot study of science curriculum effectiveness for high-ability students. Gifted Child Quarterly, 42, 200-211.

VanTassel-Baska, J., Zuo, L., Avery, L. D., \& Little, C. A. (2002). A curriculum study of gifted student learning in the language arts. Gifted Child Quarterly, 46, 30-44.

Walberg, H. (1991). Productive teaching and instruction: Assessing the knowledge base. In H. C. Waxman \& H. J. Walberg (Eds.), Effective teaching: Current research (pp. 33-62). Berkeley, CA: McCutchan. 